Article

\title{
Sustainable Land Management, Adaptive Silviculture, and New Forest Challenges: Evidence from a Latitudinal Gradient in Italy
}

\author{
Gianfranco Fabbio, Paolo Cantiani, Fabrizio Ferretti ${ }^{(\mathbb{D}}$, Umberto di Salvatore, Giada Bertini, \\ Claudia Becagli, Ugo Chiavetta ${ }^{(D)}$, Maurizio Marchi ${ }^{(D)}$ and Luca Salvati * \\ Council for Agricultural Research and Economics (CREA), Research Centre for Forestry and Wood, \\ Viale S. Margherita 80, I-52100 Arezzo, Italy; gianfranco.fabbio@crea.gov.it (G.F.); \\ paolo.cantiani@crea.gov.it (P.C.); fabrizio.ferretti@crea.gov.it (F.F.); umberto.disalvatore@crea.gov.it (U.d.S.); \\ giada.bertini@crea.gov.it (G.B.); claudia.becagli@crea.gov.it (C.B.); ugo.chiavetta@crea.gov.it (U.C.); \\ maurizio.marchi@crea.gov.it (M.M.) \\ * Correspondence: luca.salvati@crea.gov.it; Tel.: +39-575-353-021
}

Received: 12 June 2018; Accepted: 16 July 2018; Published: 18 July 2018

\begin{abstract}
Aimed at reducing structural homogeneity and symmetrical competition in even-aged forest stands and enhancing stand structure diversity, the present study contributes to the design and implementation of adaptive silvicultural practices with two objectives: (1) preserving high wood production rates under changing environmental conditions and (2) ensuring key ecological services including carbon sequestration and forest health and vitality over extended stand life-spans. Based on a quantitative analysis of selected stand structure indicators, the experimental design was aimed at comparing customary practices of thinning from below over the full standing crop and innovative practices of crown thinning or selective thinning releasing a pre-fixed number of best phenotypes and removing direct crown competitors. Experimental trials were established at four beech forests along a latitudinal gradient in Italy: Cansiglio, Veneto; Vallombrosa, Tuscany; Chiarano, Abruzzo; and Marchesale, Calabria). Empirical results indicate a higher harvesting rate is associated with innovative practices compared with traditional thinning. A multivariate discriminant analysis outlined significant differences in post-treatment stand structure, highlighting the differential role of structural and functional variables across the study sites. These findings clarify the impact of former forest structure in shaping post-treatment stand attributes. Monitoring standing crop variables before and after thinning provides a basic understanding to verify intensity and direction of the applied manipulation, the progress toward the economic and ecological goals, as well as possible failures or need for adjustments within a comprehensive strategy of adaptive forest management.
\end{abstract}

Keywords: adaptive forest management; pro-active silviculture; experimental trial; beech; Italy

\section{Introduction}

Forest ecosystems provide multiple goods and benefits by providing wood and non-wood production, protective and recreational functions, and conserving types and levels of biological diversity [1,2]. In Europe, forests have been cultivated across centuries mainly for timber production. The applied cultivation rules accelerated the simplification of stand structures, leveling out the former arrangements and further standardizing their ecological features [3,4]. Today, trees are growing at a sustained rate and many public-owned forests are experiencing an increase in customary life-span [5,6]. The underlying reasons for this phenomenon are manifold and include: (1) less intensive cultivation techniques mixing wood harvest with non-economic targets [7,8], (2) the positive impact 
of nitrogen fertilization on stand growth [9], (3) a (more or less) rapid shift of specific environmental factors (e.g., carbon dioxide $\left(\mathrm{CO}_{2}\right)$ rate, air temperature, rainfall variability) [10], and (4) a higher level of land protection [11-13] under the assumption that silviculture tailored to wood production alone is no longer suited to handle the follow-up of new forestry targets [14-16]. Evidence of higher forest productivity and delayed positive growth trends have been derived from the comparison of current growth rates with those recorded in the yield models produced up to the mid-1980s [6,17-20]. Consistently, the planned ages of final harvesting and regeneration cuttings have become a more flexible concept, adaptable to multiple economic factors and socio-environmental tasks [21,22].

Increasing ecological disturbances, such as global warming, extreme events including severe droughts, storms, fires, and acidifying pollution, have a negative impact on forestry [23-27]. Investigation into the complex relationships between environmental factors and forestry have highlighted the role of multiple drivers of change and the onset of limiting factors and feedback [28-35]. Intensity and direction of change and its cumulative effects require a permanent assessment of ecological conditions and a thorough analysis and implementation of silvicultural practices adapting to new environmental contexts $[19,36]$. An additional issue is the potential role of forests in the mitigation of climate change through the maintenance and enhancement of carbon sequestration rate. This adds a new target to sustainable forest management, calling for innovative silvicultural practices specifically aimed at promoting the role of forests as carbon sinks [2,22,37]. Monitoring tree growth levels and spatial patterns under different practices contributes to an improved understanding of environmental processes, providing an advanced knowledge base from which to adjust forest management to new socioeconomic conditions and ecological targets [13,38,39].

Based on these premises, the goal of our study was to assess the effectiveness of customary and innovative practices in meeting multiple economic-environmental objectives that include (1) the reduction in stand homogeneity and symmetrical competition, (2) the conservation of patch variability within the horizontal and vertical stand structure providing habitats and ecological niches, and (3) the maintenance of tree growth, tree health and vitality, and carbon storage and sequestration ability over increased life-spans. Different innovative and customary practices were analyzed comparatively in four beech forests along a latitudinal gradient in Italy that reflect different biophysical, ecological, and socioeconomic conditions [30,40]. The resulting findings provide empirical knowledge that support the implementation of forestry adapting to new environmental and economic challenges [36].

\section{Materials and Methods}

\subsection{Study Area}

Experimental trials were completed at 4 beech forests along a latitudinal gradient from the pre-Alps to the southern Apennines in Italy: (1) Cansiglio, Veneto, aged 120-140 years old; (2) Vallombrosa, Tuscany (110-160 years old); (3) Chiarano, Abruzzo, (70 years old); and (4) Marchesale, Calabria (75 years old). Standing crop attributes reflect previous silvicultural cycles and cultivation techniques used by local management. Soil depth and climate (Table 1) were optimal for beech vegetation at all sites. The Cansiglio beech forest was managed since the 14th century under the Republic of Venice. The first management plan dates back to 1638, whereas the establishment of a 'National forest' site is dated 1871 and the first modern silvicultural plan was implemented in 1930 . Stand regeneration has been successfully established by the shelterwood system and the current uniform structure has been shaped by long-lasting standard techniques aimed at obtaining a valuable timber production throughout the established forest compartments. Background ecological conditions make this area characteristic of pre-alpine beech forests in Italy. Vallombrosa is a widely-known beech forest where management history has been closely linked to forestry practices held by the local Benedictine Abbey. Standing crops originated from seed, with forestation of pastures beyond the pristine forest edge, and conversion of former coppice stands into high forest. Current stand structures vary from regular, dense, one-layered, with upper-inserted crowns arrangements, to a more 
heterogeneous configuration typical of former coppice stands. This configuration was created by scattered, grown-up standards, with deeper crowns and lateral branching surrounded by the stems selected on the original stools, now indiscernible from trees originated from seed.

Table 1. Basic characteristics of the study sites.

\begin{tabular}{ccc}
\hline Variable & \multicolumn{2}{c}{ Site Characteristic } \\
\cline { 2 - 3 } & Cansiglio & Vallombrosa \\
\hline Area (ha) & $30-35$ & 30 \\
Geographical coordinates (UTM-WGS84) & $46^{\circ} 03^{\prime} \mathrm{N}, 12^{\circ} 23^{\prime} \mathrm{E}$ & $43^{\circ} 44^{\prime} \mathrm{N}, 11^{\circ} 34^{\prime} \mathrm{E}$ \\
Altitudinal range (m at sea level) & $1100-1200$ & $470-1440$ \\
Landscape morphology & Gently sloping mountainsides and plains & Gently sloping mountainsides \\
Bedrock & Limestone, marlstone (Cretaceous) & Sandstone (Chianti formation) \\
Mean Temp $\left({ }^{\circ} \mathrm{C}\right)$ & 5.6 & 9.7 \\
Max. Temp $\left({ }^{\circ} \mathrm{C}\right.$, average warmest month) & 14.8, August & 24.1 July \\
Min. Temp $\left({ }^{\circ} \mathrm{C}\right.$, average coldest month) & -4.0, January & -0.8, January \\
Total Rainfall (mm) & 2004 & 1337 \\
\hline Area (ha) & Chiarano & Marchesale \\
\hline Geographical coordinates (UTM-WGS84) & 30 & 30 \\
Elevation range (m a.s.l.) & $41^{\circ} 51^{\prime} \mathrm{N}, 13^{\circ} 57^{\prime} \mathrm{E}$ & $38^{\circ} 30^{\prime} \mathrm{N}, 16^{\circ} 14^{\prime} \mathrm{E}$ \\
Landscape morphology & $1700-1800$ & 1100 \\
Bedrock & upper mountain slope & uneven mountain terrain \\
Mean Temp $\left({ }^{\circ} \mathrm{C}\right)$ & range $22^{\circ} \div 28.5^{\circ}$ & (slope up to $40 \%)$ \\
cretaceous limestone & 8.5 & granite $($ Serra and Sila formation) \\
Max. Temp $\left({ }^{\circ} \mathrm{C}\right.$, average warmest month) & 17.0, July & 10.1 \\
Min. Temp $\left({ }^{\circ} \mathrm{C}\right.$, average coldest month) & -0.2, January & 18.4, July \\
Total Rainfall (mm) & 1000 & 2.2, February \\
& & 1808 \\
\hline
\end{tabular}

The Chiarano forest is a typical Apennine beech transitory crop (i.e., a coppice forest undergoing conversion into high forest) established at the end of coppice harvesting in the mid-1990s. Periodical thinning was performed for reducing the number of shoots on each stool and maintaining a full crown cover throughout the conversion cycle. The number of standards is quite low, creating a homogeneous stand structure. The age-related tree density is relatively high with small-sized and upper-inserted crowns. A marked symmetrical competition is typical of this stand. The Marchesale forest well-depicts the heritage of Southern Italy beech forests, created through a distinct management history characteristic of highly diversified Mediterranean-mountain environments, in comparison with the homogeneous ecological contexts typical of the Alpine region. In this area, the last, unfinished regeneration cutting was intended as a mix between shelterwood, clear-cut, and clear-cut with reserves systems. Silver fir mother trees and their regeneration cohorts scattered within the dominant beech forest provide further spots of structural diversity. The resulting structure was the least regular amongst the investigated sites.

\subsection{Logical Framework}

Socioeconomic sustainability of silviculture is the basic requirement for its enforcement in forest management [30-32]. In this regard, mass tending of a standing crop is the customary technique evaluated in this study and common to all sites. Besides place-specific attributes, thinning criteria are based on the requirements of beech and aimed at obtaining quality timber. This technique well-matches the specific shade tolerance and the natural tendency to build an even-aged, one-storied stand. The working hypothesis moved from the assumption that a proactive silviculture facing the emerging environmental changes has to meet the increasing demand for climate change mitigation, while maintaining tree growth rate and promoting biological diversity. Carbon sequestration implies the maintenance of a consistent growth efficiency for the expected prolongation of stand life-time, ensuring the healthy and vital conditions in forests [41]. In the meantime, adaptive practices can reduce the current evenness while implementing cost-effective interventions. Silviculture on the tree canopy, i.e., the physical layer where tree growth occurs, was specifically addressed in this study. We assumed that the design of adaptive practices could manipulate the main crown layer to (1) create 
further growing space, (2) promote a more effective crown-stem-root ratio, and (3) ensure further growth, creating patches inside that host more diverse living communities [42].

Basically, silvicultural practices changed from a mass tending philosophy to a targeted main crop tending vision that promotes the balanced growth of the best phenotypes or a set of selected trees within the dominant layer, called 'crown' and 'selective' thinning practices, respectively. These practices occur during the intermediate ages of stand lifespan, whereas the traditional application was routinely applied since the early stages of stand development. Both the methods and context of practice implementation are therefore typical of an adaptive approach $[39,42-46]$. This task was performed by the survey of routine measurement variables and a few selected indexes of stand structure to create a cost-effective descriptive tool. Index selection was based on relevant literature $[4,18,47-50]$ and author expertise in earlier studies focusing on forest stand structure assessment [51,52]. Tree volume and biomass were calculated according to the allometric relationships implemented within the National Forest Inventory [53]. A statistical analysis was finally applied to the collected dataset with to verify the differential impact of applied silviculture on former forest structure, identifying the variables most discriminating amongst types of thinning.

A wide area (30 hectares), divided into 9 compartments, was used as the operational scale at each site. The experimental design allowed a comparative analysis of 3 silvicultural treatments (customary, innovative, and control) randomly assigned to each of the 9 compartments partitioning each site, with 3 replicates per treatment (Figure 1). In accordance with earlier studies [49,54], a cluster of 3 circular sampling plots (radius $=20 \mathrm{~m}$ ) was established within each compartment to survey the measurement variables and a set of stand structure indicators before and immediately after treatment was calculated accordingly (Table 2). The contagion index and diameter differentiation index were calculated according to the 4 and 3 nearest neighbors to the reference tree, respectively. Indexes were computed for all trees in the plot and then values were averaged. Customary silviculture involved thinning from below throughout the full standing crop. Practices consisted of (1) crown thinning at the older sites, Cansiglio and Vallombrosa; (2) selective thinning releasing a pre-fixed number of trees ( 40 or 80 per hectare at Chiarano, 0 to 45 at Marchesale), and removal of direct crown competitors. 'Control' indicates no intervention/practice and represents a possible management choice in a scenario without management, foreseeable on many Alpine and Apennine beech stands $[40,55,56]$.

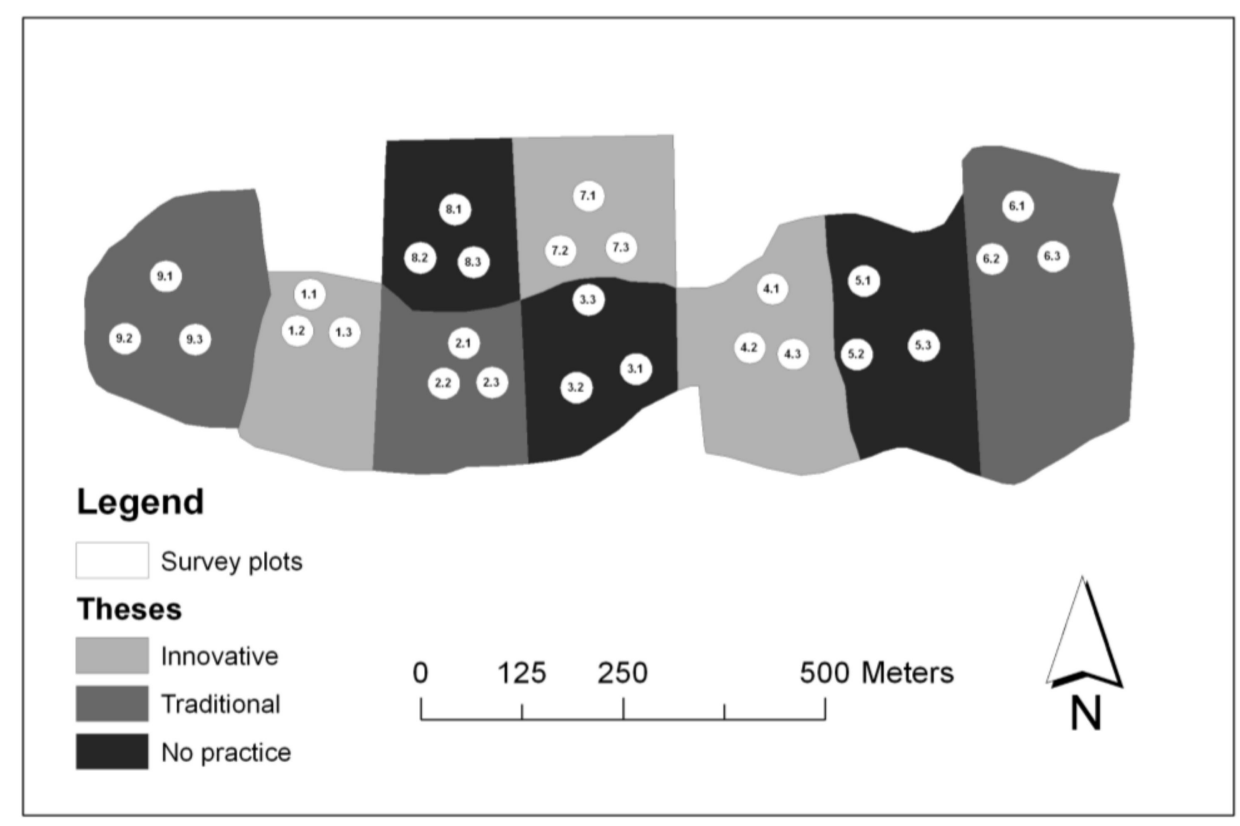

Figure 1. Layout of the experimental design at each site. Example provided from the Cansiglio Forest. 


\subsection{Statistical Analysis}

Exploratory, one-way statistical comparisons between the studied forest variables (Table 2) observed before and after treatment (control, customary, and innovative thinning, [51,64,72]) were run to test for significant differences in the statistical distribution of each indicator using a non-parametric Kruskal-Wallis ANOVA [57]. Pair-wise comparisons between forest attributes under traditional and innovative treatments were completed to test for significant differences in the statistical distribution of each indicator using non-parametric Mann-Whitney U statistic tests. In both cases, significance was determined as $p<0.05$ after Bonferroni's correction for multiple comparisons. Non-parametric inference was used to overcome statistical problems linked with the assumption of variables' normality, which is at the base of parametric inference. In this regard, whereas non-parametric tests can overcome the lack of fitting of the data to a given statistical distribution, they are only moderately effective in detecting differences for variables with similar average (or median) values and large variability.

Table 2. List of measurements and stand structure variables.

\begin{tabular}{|c|c|c|c|c|}
\hline Acronym & Name & Short Description & Unit/Algorithm & Variable \\
\hline Den & Tree density (M) & & $\mathrm{Nha}^{-1}$ & \\
\hline Bas & Tree basal area (M) & & $\mathrm{m}^{2} \mathrm{ha}^{-1}$ & \\
\hline Hei & Mean tree height $(\mathrm{M})$ & & $\mathrm{m}$ & \\
\hline Dia & Mean tree diameter $(\mathrm{M})$ & & $\mathrm{cm}$ & \\
\hline Bio & Tree biomass (M) & (dry weight) & $\mathrm{Mg} \mathrm{ha}^{-1}$ & \\
\hline CE & Clark Evans index ${ }^{1}(S)$ & $\begin{array}{l}\text { Horizontal structure-index } \\
\text { of aggregation }\end{array}$ & 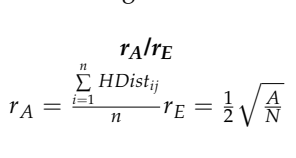 & $\begin{array}{l}\text { HDist }_{i j}=\text { Euclidean distance } \\
\text { between } i \text { th tree and its } \\
\text { nearest neighbor } \\
A=\text { plot area } \\
N=\text { plot tree number }\end{array}$ \\
\hline W & Contagion index ${ }^{2}(\mathrm{~S})$ & $\begin{array}{c}\text { Horizontal } \\
\text { structure-index of } \\
\text { neighborhood pattern }\end{array}$ & $\frac{1}{n} \times \sum_{j}^{n} v_{i j}$ & $v_{\mathrm{ij}}=1 \alpha_{\mathrm{j}}<\alpha_{0} v_{\mathrm{ij}}=0$ otherwise \\
\hline A & Species profile index ${ }^{3}(\mathrm{~S})$ & $\begin{array}{l}\text { Vertical structure-index } \\
\text { of specific abundance in } \\
\text { the profile }\end{array}$ & $-\sum_{i}^{S} \sum_{j}^{B} \pi i j \times \ln (\pi i j)$ & $\begin{array}{l}S=\text { number of different } \\
\text { tree species } \\
B=\text { number of height bands }=3\end{array}$ \\
\hline $\mathrm{T}$ & $\begin{array}{l}\text { Diameter differentiation } \\
\text { index }^{4}(\mathrm{~S})\end{array}$ & $\begin{array}{c}\text { Dimensional } \\
\text { structure-spatial } \\
\text { distribution of tree sizes }\end{array}$ & $\frac{1}{n} \times \sum_{i}^{n}(1-\underset{i}{r})$ & $\begin{array}{l}r_{i}=(\text { thinner } \mathrm{dbh}) /(\text { thicker } \mathrm{dbh}) \\
\text { of tree pair } i \\
n=\text { number of measured } \\
\text { tree pairs }\end{array}$ \\
\hline$C V_{\mathrm{dbh}}$ & $\begin{array}{c}\text { Diameter at breast height } \\
\text { (dbh) coefficient of } \\
\text { variation }(S)\end{array}$ & $\begin{array}{l}\text { Dimensional } \\
\text { structure-relative } \\
\text { variability of tree } \\
\text { size distribution }\end{array}$ & $\%$ & \\
\hline
\end{tabular}

A linear stepwise discriminant analysis was finally performed on the full indicators' matrix separately for each forest site after variable standardization. The analysis was aimed at identifying and ranking the importance of the most relevant indicators [58,59], if any, discriminating among silvicultural treatments. The discriminant analysis was developed using a forward stepwise approach with Fisher-Snedecor statistic $(F)$-to-remove and $F$-to-enter criteria corresponding to a $p$-level $<0.05$ and $<0.1$, respectively. The model diagnostics used included (1) Wilks' lambda, (2) Fisher-Snedecor statistic $(F)$ testing for significant differences among treatments, and (3) the percentage of correctly classified cases [60]. A Mahalanobis' distance between control, traditional, and innovative thinning was computed to identify treatments significantly impacting the investigated stand structures.

\section{Results}

Values of the measurement variables at the time of survey (Table 3) ranged across the sites as a function of site potential productivity, main stand age, origin (seed or agamic), and cultivation history (namely the applied regeneration cutting type and thinning regime over the full life-span). Tree density decreased as a function of stand age and thinning intensity, reflecting random-to-clustered distribution patterns. A specific comparison of tree density at Cansiglio and Vallombrosa forests-two stands of 
similar age-highlights the more conservative management at the latter site, whereas Marchesale forest demonstrated inner tree density variability due to the patchy release of trees during the former cycle, which are still standing. Conversely, Chiarano forest displayed the highest tree density, typical of a coppice undergoing conversion into high forest.

Table 3. Measurement variables at the study sites (mean \pm standard deviation).

\begin{tabular}{ccccc}
\hline Variable & Cansiglio & Vallombrosa & Chiarano & Marchesale \\
\hline Tree density & $323 \pm 65.9$ & $532 \pm 117$ & $1367 \pm 353$ & $510 \pm 130$ \\
Basal area $\left(\mathrm{m}^{2}\right)$ & $40.9 \pm 5.2$ & $54.9 \pm 3.5$ & $38.8 \pm 4.4$ & $41.2 \pm 7.3$ \\
Mean height $(\mathrm{m})$ & $26.6 \pm 0.5$ & $28.2 \pm 1.6$ & $14.3 \pm 0.8$ & $23.3 \pm 1.5$ \\
Mean dbh $(\mathrm{cm})$ & $40.6 \pm 3$ & $37.3 \pm 5.6$ & $19.4 \pm 2.4$ & $32.9 \pm 6.1$ \\
Dominant dbh $(\mathrm{cm})$ & $49 \pm 3.6$ & $50.5 \pm 6.0$ & $35.8 \pm 4.6$ & $54.0 \pm 6.8$ \\
Dominant height $(\mathrm{m})$ & $27 \pm 0.6$ & $31.9 \pm 1.2$ & $18.0 \pm 0.9$ & $27.7 \pm 1.2$ \\
Standing volume $\left(\mathrm{m}^{3}\right)$ & $543 \pm 72$ & $795 \pm 80.3$ & $183 \pm 24.4$ & $497 \pm 110.8$ \\
\hline
\end{tabular}

Basal area was age-dependent but less sensitive to tree density variability where crown cover is complete and the growing space fully-stocked. The higher basal area at Vallombrosa in comparison with Cansiglio depended on the higher tree density and the greater efficiency in space occupancy, due to the complementary dendrotypes filling up the living space. Trees from the prior cycle increased the dominant height at Marchesale, despite the relatively young age of the stand. Standing volume was consistent with the other measurement variables, reaching its peak at Vallombrosa (nearly $800 \mathrm{~m}^{3} \mathrm{ha}^{-1}$ ). At Marchesale, the relatively high tree density and the similar dominant tree height increased the standing volume close to the values recorded at Cansiglio, confirming earlier evidence on the high productivity of southern beech forests (Table 4).

Table 4. Average values of the measurement variables (mean) and structural indexes (median \pm standard deviation) at the study sites by treatment.

\begin{tabular}{|c|c|c|c|c|c|c|c|c|c|c|}
\hline \multirow{3}{*}{ Variable } & \multicolumn{6}{|c|}{ Cansiglio } & \multicolumn{4}{|c|}{ Vallombrosa } \\
\hline & \multicolumn{3}{|c|}{ Before Thinning } & \multicolumn{3}{|c|}{ After Thinning } & \multicolumn{2}{|c|}{ Before Thinning } & \multicolumn{2}{|c|}{ After Thinning } \\
\hline & Innovative & \multicolumn{2}{|c|}{ Customary } & \multicolumn{2}{|c|}{ Innov. } & Custom. & Innov. & Custom. & Innov. & Custom. \\
\hline Tree density & 320 & \multicolumn{2}{|c|}{326} & \multicolumn{2}{|c|}{187} & 235 & 511 & 598 & 316 & 567 \\
\hline Basal area $\left(\mathrm{m}^{2}\right)$ & 41.8 & \multicolumn{2}{|c|}{40.7} & \multicolumn{2}{|c|}{26.3} & 30.3 & 56.9 & 54.3 & 36.4 & 52.6 \\
\hline Mean height $(\mathrm{m})$ & 26.8 & \multicolumn{2}{|c|}{26.5} & \multicolumn{2}{|c|}{27.0} & 26.5 & 28.5 & 27.7 & 26.4 & 25.3 \\
\hline Mean dbh $(\mathrm{cm})$ & 40.3 & \multicolumn{2}{|c|}{40.1} & \multicolumn{2}{|c|}{43.7} & 40.5 & 38.5 & 34.5 & 30.0 & 27.0 \\
\hline Dominant dbh $(\mathrm{cm})$ & 49.6 & \multicolumn{2}{|c|}{47.8} & \multicolumn{2}{|c|}{48.1} & 46.9 & 61.0 & 50.1 & 58.9 & 50.1 \\
\hline Dominant height (m) & 27.8 & \multicolumn{2}{|c|}{27.6} & \multicolumn{2}{|c|}{27.0} & 26.6 & 33.6 & 31.4 & 33.2 & 31.4 \\
\hline Standing volume $\left(\mathrm{m}^{3}\right)$ & 561 & \multicolumn{2}{|c|}{529} & \multicolumn{2}{|c|}{358} & 402 & 838 & 768 & 542 & 741 \\
\hline Bio & $360.6 \pm 35$ & \multicolumn{2}{|c|}{$342.6 \pm 53$} & \multicolumn{2}{|c|}{$230.8 \pm 43$} & $287.8 \pm 32$ & $495.0 \pm 87$ & $472.5 \pm 130$ & $321.75 \pm 17$ & $496.13 \pm 28$ \\
\hline$C E$ & $1.25 \pm 0.12$ & \multicolumn{2}{|c|}{$1.26 \pm 0.1$} & \multicolumn{2}{|c|}{$1.4 \pm 0.2$} & $1.34 \pm 0.1$ & $1.33 \pm 0.11$ & $1.28 \pm 0.10$ & $1.38 \pm 0.12$ & $1.28 \pm 0.1$ \\
\hline $\mathrm{W}$ & $0.63 \pm 0.02$ & \multicolumn{2}{|c|}{$0.63 \pm 0.03$} & 0.65 & 0.11 & $0.63 \pm 0.12$ & $0.63 \pm 0.07$ & $0.62 \pm 0.03$ & $0.67 \pm 0.16$ & $0.62 \pm 0.13$ \\
\hline A & $0.40 \pm 0.11$ & & $=0.12$ & 0.39 & 0.12 & $0.37 \pm 0.15$ & $0.85 \pm 0.16$ & $0.85 \pm 0.13$ & $0.84 \pm 0.14$ & $0.85 \pm 0.16$ \\
\hline $\mathrm{T}$ & $0.17 \pm 0.04$ & & 0.04 & 0.18 & 0.04 & $0.17 \pm 0.03$ & $0.21 \pm 0.04$ & $0.23 \pm 0.05$ & $0.24 \pm 0.04$ & $0.23 \pm 0.04$ \\
\hline CVdbh & $20.1 \pm 5.0$ & & $=4.40$ & 17.2 & 3.7 & $20.84 \pm 4.3$ & $25.3 \pm 4.6$ & $22.7 \pm 4.9$ & $27.32 \pm 4.2$ & $22.7 \pm 5.3$ \\
\hline & & & Chiar & & & & & Marc & esale & \\
\hline & Bef & Thin & & & ter Th & ning & Before & hinning & After & inning \\
\hline & I-80 & I-40 & Custom. & $\mathrm{I}-80$ & I-40 & Custom. & Innov. & Custom. & Innov. & Custom. \\
\hline Tree density & 1293 & 1515 & 1293 & 684 & 655 & 613 & 528 & 479 & 409 & 408 \\
\hline Basal area $\left(\mathrm{m}^{2}\right)$ & 40.3 & 39.9 & 36.1 & 23.1 & 24.2 & 23.5 & 43.5 & 38.7 & 33.7 & 31.6 \\
\hline Mean height (m) & 14.1 & 14.6 & 14.3 & 15.0 & 15.1 & 15.3 & 23.4 & 23.5 & 24.2 & 23.5 \\
\hline Mean dbh $(\mathrm{cm})$ & 20.3 & 18.6 & 19.3 & 22.8 & 21.7 & 21.7 & 32.3 & 32.5 & 33.0 & 33.4 \\
\hline Dominant dbh $(\mathrm{cm})$ & 36.5 & 35.5 & 36.2 & 36.0 & 35.1 & 36.1 & 42.7 & 55.8 & 54.2 & 48.8 \\
\hline Dominant height (m) & 18.2 & 18.0 & 18.2 & 18.1 & 17.9 & 18.1 & 25.6 & 27.9 & 27.6 & 26.7 \\
\hline Standing volume $\left(\mathrm{m}^{3}\right)$ & 304 & 292 & 272 & 180 & 192 & 177 & 528 & 468 & 401 & 377 \\
\hline Bio & $185.2 \pm 21$ & & \pm 25 & 112. & \pm 12 & $117 \pm 18$ & $338.9 \pm 97.1$ & $278.1 \pm 60.6$ & $267.7 \pm 45$ & $239.2 \pm 54$ \\
\hline CE & $1.13 \pm 0.13$ & & $=0.11$ & 1.19 & 0.22 & $1.21 \pm 0.14$ & $1.17 \pm 0.31$ & $1.19 \pm 0.13$ & $1.26 \pm 0.12$ & $1.26 \pm 0.15$ \\
\hline $\mathrm{W}$ & $0.62 \pm 0.03$ & & 0.02 & 0.62 & 0.15 & $0.64 \pm 0.13$ & $0.63 \pm 0.02$ & $0.62 \pm 0.04$ & $0.65 \pm 0.17$ & $0.62 \pm 0.12$ \\
\hline A & $0.93 \pm 0.09$ & & $=0.05$ & 0.83 & 0.15 & $0.82 \pm 0.14$ & $0.94 \pm 0.12$ & $0.89 \pm 0.32$ & $0.96 \pm 0.12$ & $0.85 \pm 0.1$ \\
\hline $\mathrm{T}$ & $0.27 \pm 0.03$ & & $=0.04$ & 0.26 & 0.03 & $0.18 \pm 0.2$ & $0.24 \pm 0.03$ & $0.25 \pm 0.04$ & $0.24 \pm 0.01$ & $0.26 \pm 0.02$ \\
\hline CVdbh & $28.8 \pm 4.9$ & 26 & \pm 5.5 & 24.7 & 4.9 & $19.35 \pm 5.4$ & $31.2 \pm 6.9$ & $31.2 \pm 6.4$ & $31.51 \pm 4.5$ & $31.82 \pm 44.1$ \\
\hline
\end{tabular}

* Three treatments (Customary, Innovative-80, I-80, Innovative-40, I-40) were investigated at Chiarano. I-80 and I-40 were considered together in the statistical analysis when compared with the other sites. 
Empirical data highlight the heavier harvesting in the innovative treatment than in customary practice at all sites as far as number of trees, basal area, and standing volume were concerned. According to the innovative criterion, the removal rate in the basal area and volume were quite similar to Cansiglio and Vallombrosa and more intense (up to $40 \%$ ) at Chiarano, which contains a particularly dense forest. The removal rate at Marchesale was about one-half of that at Chiarano (Table 5), with tree density being about one-third that of Chiarano. The customary removal was close to zero at Vallombrosa because local staff strictly followed the planned time ruled by the approved management plan, removing only damaged trees. Conversely, the apparent change in mean diameter and tree height was the outcome of the different layer(s) manipulated by each thinning type. Figure 2 provides a representative example of the values of crown overlapping, crown layer texture (i.e., gap size and shape), spatial arrangement, fragmentation, and connection before and after thinning operation at Cansiglio, evidencing the relevant change driven by innovative thinning within this layer [22].

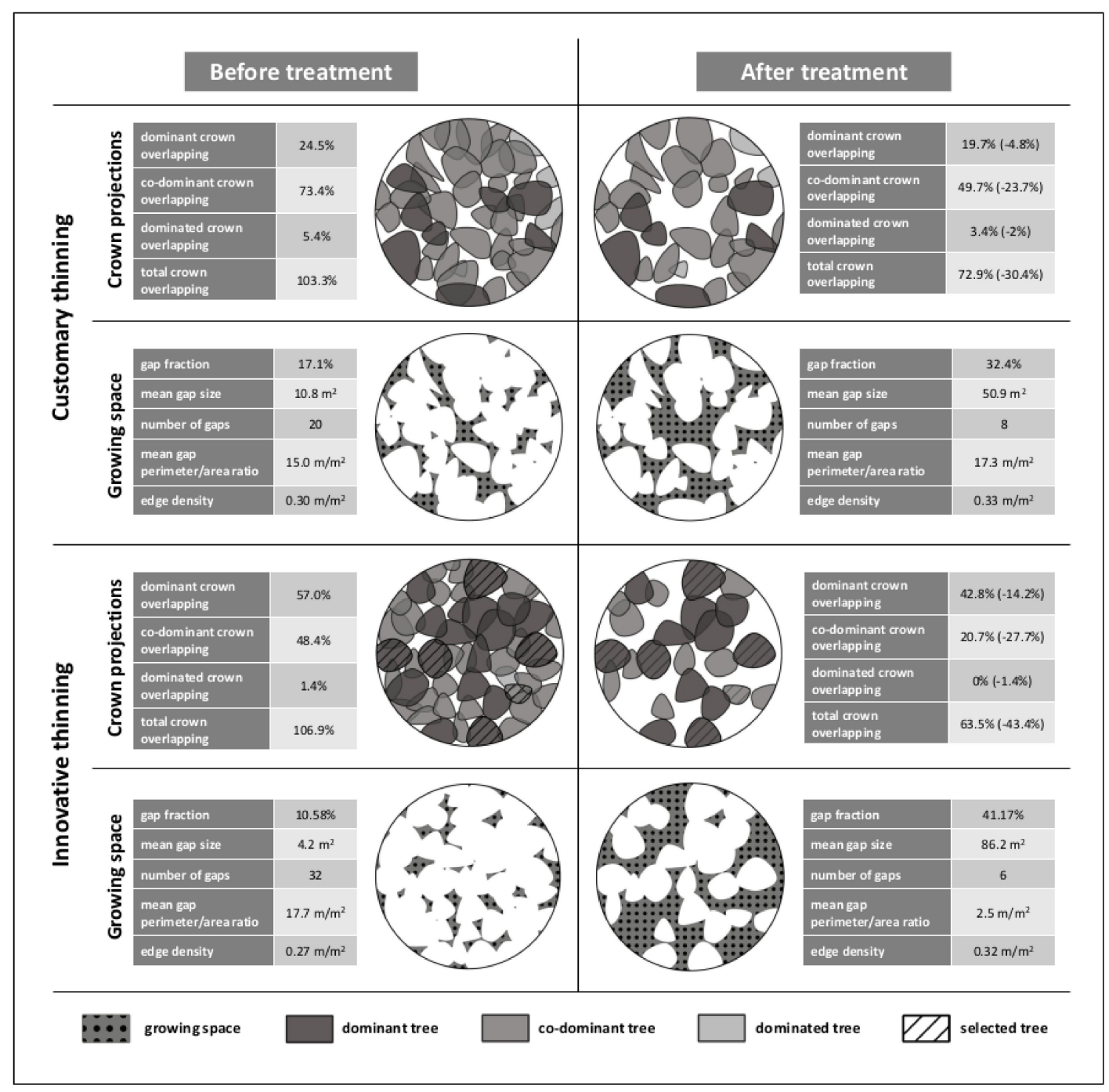

Figure 2. Crown and gap area distribution at one sample plot, before and after each thinning type at Cansiglio (following Fabbio et al. [22], supplemented with figures). 
Table 5. Percentage of removal at the four study sites.

\begin{tabular}{cccc}
\hline \multirow{2}{*}{ Treatment } & \multicolumn{3}{c}{ Tree Removal (\%) } \\
\cline { 2 - 4 } & Number of Trees & Basal Area & Standing Volume \\
\hline CANSIGLIO & 41 & 37 & 36 \\
Innovative & 28 & 26 & 24 \\
Customary & & & 35 \\
VALLOMBROSA & 38 & 36 & 3 \\
Innovative & 3.6 & 3.1 & 34 \\
Customary & & 36 & 37 \\
CHIARANO & 53 & 40 & 40 \\
Customary & 47 & 41 & 24 \\
Innovative-80 & 57 & & 20 \\
Innovative-40 & & 21 & \\
MARCHESALE & 22 & 19 & \\
Innovative & 15 & & \\
Customary & & & \\
\hline
\end{tabular}

Results of the statistical analysis based on univariate and multivariate comparisons of stand structure variables among the investigated sites are illustrated in Table 6. Three variables (Den, Bio, and Bas) were significantly different among treatments (control vs. customary vs. innovative) in Cansiglio. The same differences were observed when comparing the outcome of the two silvicultural treatments separately (customary vs. innovative). In Vallombrosa, two additional variables $\left(\mathrm{T}, \mathrm{CV}_{\mathrm{dbh}}\right)$ were significantly different between treatments compared with Cansiglio.

Table 6. Results of non-parametric statistical analysis testing for differences between treatments. Only significant comparisons at $p<0.05$ after Bonferroni's correction for multiple comparisons are shown.

\begin{tabular}{|c|c|c|c|c|c|c|}
\hline \multirow{2}{*}{ Variable } & \multicolumn{3}{|c|}{ Kruskal-Wallis Analysis of Variance ${ }^{1}$} & \multicolumn{3}{|c|}{ Mann-Whitney U Test ${ }^{2}$} \\
\hline & Statistic & $p$-Value & $n$ & Statistic & $p$-Value & $n$ \\
\hline \multicolumn{7}{|c|}{ Cansiglio } \\
\hline Den & 17.9 & 0.0004 & 27 & -2.6 & 0.010 & 18 \\
\hline Bas & 21.1 & 0.0001 & 27 & -3.4 & 0.0006 & 18 \\
\hline Bio & 22.9 & 0.0000 & 27 & -3.2 & 0.001 & 18 \\
\hline \multicolumn{7}{|c|}{ Vallombrosa } \\
\hline Den & 15.8 & 0.0009 & 27 & 3.6 & 0.0003 & 18 \\
\hline Bas & 18.1 & 0.0003 & 27 & 3.6 & 0.0003 & 18 \\
\hline Bio & 18.9 & 0.0002 & 27 & 3.3 & 0.0009 & 18 \\
\hline $\mathrm{T}$ & 15.6 & 0.001 & 27 & -3.7 & 0.0002 & 18 \\
\hline $\mathrm{CV}_{\mathrm{dbh}}$ & 14.9 & 0.002 & 27 & -2.7 & 0.006 & 18 \\
\hline \multicolumn{7}{|c|}{ Chiarano } \\
\hline Den & 18.4 & 0.0001 & 27 & 0.8 & 0.40 & 18 \\
\hline Bas & 19.6 & 0.0001 & 27 & 1.8 & 0.07 & 18 \\
\hline Dia & 14.3 & 0.0008 & 27 & 0.6 & 0.57 & 18 \\
\hline Hei & 14.2 & 0.0008 & 27 & 0.3 & 0.76 & 18 \\
\hline Bio & 19.1 & 0.0001 & 27 & 1.5 & 0.12 & 18 \\
\hline CE & 9.3 & 0.0098 & 27 & 0.7 & 0.51 & 18 \\
\hline $\mathrm{T}$ & 14.7 & 0.006 & 27 & -2.5 & 0.01 & 18 \\
\hline $\mathrm{CV}_{\mathrm{dbh}}$ & 13.9 & 0.009 & 27 & -2.2 & 0.02 & 18 \\
\hline \multicolumn{7}{|c|}{ Marchesale } \\
\hline Den & 19.4 & 0.0001 & 27 & -1.7 & 0.08 & 18 \\
\hline Bas & 15.3 & 0.0005 & 27 & -1.1 & 0.29 & 18 \\
\hline Hei & 18.0 & 0.0001 & 27 & 0.2 & 0.83 & 18 \\
\hline Bio & 19.1 & 0.001 & 27 & -1.5 & 0.12 & 18 \\
\hline CE & 11.6 & 0.0031 & 27 & 0.4 & 0.69 & 18 \\
\hline
\end{tabular}

\footnotetext{
${ }^{1}$ Non-parametric statistic testing for significant differences among treatments (control vs. customary vs. innovative);

${ }^{2}$ Non-parametric statistic testing for significant differences between thinning (customary vs. innovative).
} 
In Chiarano, eight variables were significantly different between treatments, suggesting a differential impact of silviculture on this forest structure compared with the other three sites. Finally, five variables were significantly different in Marchesale (Den, Bas, Hei, Bio, and CE), similar to what was observed in Vallombrosa. Interestingly, Marchesale displayed underlying conditions similar to Vallombrosa, with site-specific differences depending exclusively on the spatial distribution of trees. Results of a linear discriminant analysis identifying the most relevant variables that differentiate customary and/or innovative treatments from control plots are presented in Table 7, evidencing how the number of discriminant variables increases along the latitudinal gradient from Cansiglio to Chiarano.

Table 7. Results of stepwise discriminant analysis among treatments by site ( ${ }^{*}$ indicates significance at $p<0.001)$.

\begin{tabular}{|c|c|c|c|c|c|c|c|c|}
\hline \multirow{2}{*}{ Variable } & \multicolumn{5}{|c|}{ Model Diagnostic } & \multicolumn{3}{|c|}{ Mahalanobis' Distance $\left(^{*} p<0.001\right)$} \\
\hline & Wilks' L & F-to-Remove & $p$-value & 1-Tolerance & Correct No. (\%) & Treatment & Customary & Control \\
\hline \multicolumn{9}{|c|}{ Cansiglio: Wilks' $\mathrm{L}=0.038, \mathrm{~F}_{(4,46)}: 47.2, p<0.0001$} \\
\hline Bio & 0.19 & 46.6 & 0.00 & 0.20 & 96.3 & Innovative & $12.2 *$ & $95.2 *$ \\
\hline Bas & 0.05 & 3.9 & 0.03 & 0.20 & & Customary & & $43.2 *$ \\
\hline Den & 0.49 & 167.0 & 0.00 & 0.25 & 96.3 & Innovative & $56.3 *$ & $67.5 *$ \\
\hline Hei & 0.06 & 11.4 & 0.0004 & 0.90 & & Customary & & $6.0^{*}$ \\
\hline Dia & 0.06 & 10.6 & 0.0006 & 0.90 & & & & \\
\hline \multicolumn{9}{|c|}{ Chiarano: Wilks' L $=0.009, \mathrm{~F}_{(10,40)}: 54.4, p<0.0001$} \\
\hline Bas & 0.01 & 11.07 & 0.0006 & 0.95 & 88.9 & Innovative & 6.4 & $438.8^{*}$ \\
\hline $\mathrm{T}$ & 0.01 & 6.77 & 0.006 & 0.08 & & Customary & & $391.1^{*}$ \\
\hline Den & 0.02 & 24.97 & 0.00001 & 0.99 & & & & \\
\hline Dia & 0.01 & 3.70 & 0.042 & 0.98 & & & & \\
\hline Hei & 0.01 & 3.50 & 0.049 & 0.99 & & & & \\
\hline \multicolumn{9}{|c|}{ Marchesale: Wilks' $\mathrm{L}=0.03, \mathrm{~F}_{(10,40)}: 18.2, p<0.0001$} \\
\hline Hei & 0.20 & 53.10 & 0.00000 & 0.57 & 77.8 & Innovative & 2.89 & $86.6 *$ \\
\hline Den & 0.10 & 21.77 & 0.00001 & 0.40 & & Customary & & $74.8^{*}$ \\
\hline A & 0.05 & 6.34 & 0.007 & 0.30 & & & & \\
\hline Dia & 0.05 & 6.13 & 0.008 & 0.40 & & & & \\
\hline
\end{tabular}

\section{Discussion}

Under the assumption that forest structure, after thinning, is the baseline condition to test the effectiveness of adaptive forestry approaches, an earlier study [51] documented the impact of silvicultural practices on forest structure at Cansiglio and Marchesale using a set of stand structure and tree competition metrics. The empirical results of our study outlined the sensitivity of tree competition indexes to changes following thinning and the ability of crown-based indexes to differentiate thinning criteria compared with measurement variables; their outcome becoming more consistent a few years after thinning [61]. Considering sites along a latitudinal gradient provided a more comprehensive understanding of stand structure following thinning in Italy. The thinning from above and selective thinning, intended as innovative practices for use within beech forests in Italy, paying special attention to the rearrangement of canopy layer since this storey has a leading role in the achievement of expected benefits from the structural attributes of forests [62-64]. In this respect, any manipulation of the upper canopy interface influences the radiation regime and throughfall, with implications for microclimate, heat and water availability, evapotranspiration, litterfall amount, decomposition rate, and respiratory losses. All these factors contribute significantly to the overall carbon budget [65-67].

Innovative thinning released much wider and less fragmented gaps, creating lasting openings at the main crown level. This is expected to shape bio-geo-chemical processes that promote new habitats and ecological niches $[68,69]$. Differentiated tree crown sizes ensure resistance to disturbances and enhance individual growth patterns within the tree population. Thinning operations provided an economic outcome at all sites and for both the applied treatments in proportion to the harvested volumes, independent of the position of the harvested trees. The high removal rate typical of the innovative criterion was sustained by a relatively high growing stock due to stand density. After thinning, the empirical analysis evidenced significant changes in an increasing number of 
forest attributes moving from Cansiglio (a homogeneous high forest) to Chiarano (a coppice forest undergoing conversion into high forest), suggesting the driving influence of former forest structure on post-treatment stand attributes.

Taken together, this study demonstrates how specific beech attributes-including the rapid ecological response to late thinning and a high crown plasticity to occupy the available space-can increase adaptability to the implemented practices [67], thus confirming the effectiveness of the selected treatments in given adaptive silvicultural practices. In this regard, the empirical results of this study also outline that the multifaceted history of stands' former treatments may play a role in the current stand structure, influencing the effectiveness of the applied thinning methods. Monitoring stand variables after silvicultural manipulation provides increased knowledge, verifying the progress toward the desired goals, identifying possible failures or needs for adjustment, helping to determine which issues must be better addressed and finely tuned with ongoing environmental changes [70-73].

\section{Conclusions}

Global changes under increasing ecological disturbances call for adaptive forest management approaches that consider drivers, feedbacks, and limiting factors, comparing heritage and new productive criteria, transitioning from the former steady condition to a more dynamic silvicultural approach. The design and implementation of innovative practices consistent with growth environments and specific bio-ecological requirements, proved to be a technically-feasible, reliable tool to tackle both ecological and economic challenges from an adaptive forestry viewpoint.

Author Contributions: P.C. and F.F. identified research questions. U.d.S. and C.B. carried out the field survey; G.B. and M.M. made the statistical analysis; U.C. made the extensive bibliographic analysis; G.F. and L.S. wrote the paper.

Funding: ManForCBD LIFE + project 'Managing Forests for multiple purpose: Carbon, Biodiversity and socio-economic wellbeing' (LIFE + 09ENV/IT000078); and Smart4Action LIFE + project 'Sustainable monitoring and reporting to inform forest- and environmental awareness and protection' (LIFE13 ENV/IT/000813).

Acknowledgments: Thanks to Maurizio Piovosi, Tiziano Sorgi and Valerio Moretti for technical assistance.

Conflicts of Interest: The authors declare no conflict of interest.

\section{References}

1. Seppelt, R.; Dormann, C.F.; Eppink, F.V.; Lautenbach, S.; Schmidt, S. A quantitative review of ecosystem service studies: Approaches, shortcomings and the road ahead. J. Appl. Ecol. 2011, 48, 630-636. [CrossRef]

2. Ray, D.; Petr, M.; Mullett, M.; Bathgate, S.; Marchi, M.; Beauchamp, K. A simulation-based approach to assess forest policy options under biotic and abiotic climate change impacts: A case study on Scotland's National Forest Estate. For. Policy Econ. 2017. [CrossRef]

3. Franklin, J.F.; Spies, T.A.; Van Pelt, R.; Carey, A.B.; Thornburgh, D.A.; Berg, D.R.; Lindenmayer, D.B.; Harmon, M.E.; Keeton, W.S.; Shaw, D.C.; et al. Disturbances and structural development of natural forest ecosystems with silvicultural implications, using Douglas-fir forests as an example. For. Ecol. Manag. 2002, 155, 399-423. [CrossRef]

4. Mc Elhinny, C.; Gibbons, P.; Brack, C.; Bauhus, J. Forest and woodland stand structural complexity: Its definition and measurement. For. Ecol. Manag. 2005, 218, 1-24. [CrossRef]

5. Spiecker, H. Overview of recent growth trends in European forests. Water Air Soil Pollut. 1999, 116, 33-46. [CrossRef]

6. Pretzsch, H.; Biber, P.; Schütze, G.; Uhl, E.; Rötzer, T. Forest stand growth dynamics in Central Europe have accelerated since 1870. Nat. Commun. 2014, 5, 4967. [CrossRef] [PubMed]

7. Schall, P.; Ammer, C. How to quantify forest management intensity in Central European forests. Eur. J. For. Res. 2013, 132, 379-396. [CrossRef]

8. Marchi, M.; Paletto, A.; Cantiani, P.; Bianchetto, E.; De Meo, I. Comparing Thinning System Effects on Ecosystem Services Provision in Artificial Black Pine (Pinus nigra J. F. Arnold) Forests. Forests 2018, 9, 188. [CrossRef] 
9. Ferretti, M.; Marchetto, A.; Arisci, S.; Bussotti, F.; Calderisi, M.; Carnicelli, S.; Cecchini, G.; Fabbio, G.; Bertini, G.; Matteucci, G.; et al. On the tracks of Nitrogen deposition effects on temperate forests at their southern European range-An observational study from Italy. Glob. Chang. Biol. 2014, 20, 3423-3438. [CrossRef] [PubMed]

10. Salvati, L.; Petitta, M.; Ceccarelli, T.; Perini, L.; Di Battista, F.; Scarascia, M.E.V. Italy's renewable water resources as estimated on the basis of the monthly water balance. Irrig. Drain. 2008, 57, 507-515. [CrossRef]

11. Grilli, G.; Nikodinoska, N.; Paletto, A.; De Meo, I. Stakeholders' preferences and economic value of forest ecosystem services: An example in the Italian alps. Balt. For. 2015, 21, $298-307$.

12. Meeus, J.H.A.; Wijermans, M.P.; Vroom, M.J. Agricultural landscapes in Europe and their transformation. Landsc. Urban Plan. 1990, 18, 289-352. [CrossRef]

13. Marchi, M.; Chiavetta, U.; Cantiani, P. Assessing the mechanical stability of trees in artificial plantations of Pinus nigra J. F. Arnold using the LWN tool under different site indexes. Ann. Silvic. Res. 2017, 41, 48-53. [CrossRef]

14. Barbati, A.; Corona, P.; Salvati, L.; Gasparella, L. Natural forest expansion into suburban countryside: Gained ground for a green infrastructure? Urban For. Urban Green. 2013, 12, 36-43. [CrossRef]

15. Corona, P.; Cutini, A.; Chiavetta, U.; Paoletti, E. Forest-food nexus: A topical opportunity for human well-being and silviculture. Ann. Silvic. Res. 2016, 40,1-10. [CrossRef]

16. Tomao, A.; Antonio, J.; Martínez, J.; Aragón, D. Is silviculture able to enhance wild forest mushroom resources? Current knowledge and future perspectives. For. Ecol. Manag. 2017, 402, 102-114. [CrossRef]

17. Duncker, P.S.; Raulund-Rasmussen, K.; Gundersen, P.; Katzensteiner, K.; De Jong, J.; Ravn, H.P.; Smith, M.; Eckmüllner, O.; Spiecker, H. How forest management affects ecosystem services, including timber production and economic return: Synergies and trade-offs. Ecol. Soc. 2012, 17, 50. [CrossRef]

18. Pretzsch, H. Forest Dynamics, Growth and Yield; Springer: Berlin/Heidelberg, Germany, 2009; ISBN 978-3-540-88306-7.

19. Bertini, G.; Amoriello, T.; Fabbio, G.; Piovosi, M. Forest growth and climate change: Evidences from the ICP-Forests intensive monitoring in Italy. iForest-Biogeosci. For. 2011, 4, 262-267. [CrossRef]

20. Marchi, M.; Ferrara, C.; Bertini, G.; Fares, S.; Salvati, L. A sampling design strategy to reduce survey costs in forest monitoring. Ecol. Indic. 2017, 81, 182-191. [CrossRef]

21. O'Hara, K.L. What is close-to-nature silviculture in a changing world? Forestry 2016, 89, 1-6. [CrossRef]

22. Fabbio, G.; Cantiani, P.; Ferretti, F.; Chiavetta, U.; Bertini, G.; Becagli, C.; Di Salvatore, U.; Bernardini, V.; Tomaiuolo, M.; Matteucci, G.; et al. Adaptive silviculture to face up to the new challenges: The ManForC.BD experience. In Proceedings of the 2nd International Congress of Silviculture, Florence, Italy, 26-29 November 2014; pp. 531-538.

23. Bengtsson, J.; Nilsson, S.G.; Franc, A.; Menozzi, P. Biodiversity, disturbances, ecosystem function and management of European forests. For. Ecol. Manag. 2000, 132, 39-50. [CrossRef]

24. Millar, C.I.; Stephenson, N.L.; Stephens, S.L. Climate change and forests of the future: Managing in the face of uncertainty. Ecol. Appl. 2007, 17, 2145-2151. [CrossRef] [PubMed]

25. Milad, M.; Schaich, H.; Bürgi, M.; Konold, W. Climate change and nature conservation in Central European forests: A review of consequences, concepts and challenges. For. Ecol. Manag. 2011, 261, 829-843. [CrossRef]

26. Nabuurs, G.J.; Lindner, M.; Verkerk, P.J.; Gunia, K.; Deda, P.; Michalak, R.; Grassi, G. First signs of carbon sink saturation in European forest biomass. Nat. Clim. Chang. 2013, 3, 792-796. [CrossRef]

27. Seidl, R.; Schelhaas, M.J.; Rammer, W.; Verkerk, P.J. Increasing forest disturbances in Europe and their impact on carbon storage. Nat. Clim. Chang. 2014, 4, 806-810. [CrossRef] [PubMed]

28. Magnani, F.; Mencuccini, M.; Borghetti, M.; Berbigier, P.; Berninger, F.; Delzon, S.; Grelle, A.; Hari, P.; Jarvis, P.G.; Kolari, P.; et al. The human footprint in the carbon cycle of temperate and boreal forests. Nature 2007, 447, 848-850. [CrossRef] [PubMed]

29. De Vries, W.; Solberg, S.; Dobbertin, M.; Sterba, H.; Laubhahn, D.; Reinds, G.J.; Nabuurs, G.-J.; Gundersen, P.; Sutton, M.A. Ecologically implausible carbon response? Nature 2008, 451, E1-E3. [CrossRef] [PubMed]

30. Ferrara, C.; Carlucci, M.; Grigoriadis, E.; Corona, P.; Salvati, L. A comprehensive insight into the geography of forest cover in Italy: Exploring the importance of socioeconomic local contexts. For. Policy Econ. 2017, 75, 12-22. [CrossRef]

31. Solberg, S.; Dobbertin, M.; Reinds, G.J.; Lange, H.; Andreassen, K.; Fernandez, P.G.; Hildingsson, A.; de Vries, W. Analyses of the impact of changes in atmospheric deposition and climate on forest growth in European monitoring plots: A stand growth approach. For. Ecol. Manag. 2009, 258, 1735-1750. [CrossRef] 
32. Etzold, S.; Waldner, P.; Thimonier, A.; Schmitt, M.; Dobbertin, M. Tree growth in Swiss forests between 1995 and 2010 in relation to climate and stand conditions: Recent disturbances matter. For. Ecol. Manag. 2014, 311, 41-55. [CrossRef]

33. Stephenson, N.L.; Das, A.J.; Condit, R.; Russo, S.E.; Baker, P.J.; Beckman, N.G.; Coomes, D.A.; Lines, E.R.; Morris, W.K.; Rüger, N.; et al. Rate of tree carbon accumulation increases continuously with tree size. Nature 2014, 507, 90-93. [CrossRef] [PubMed]

34. Biasi, R.; Colantoni, A.; Ferrara, C.; Ranalli, F.; Salvati, L. In-between sprawl and fires: Long-term forest expansion and settlement dynamics at the wildland-urban interface in Rome, Italy. Int. J. Sustain. Dev. World Ecol. 2015, 22, 467-475. [CrossRef]

35. Bajocco, S.; Ceccarelli, T.; Smiraglia, D.; Salvati, L.; Ricotta, C. Modeling the ecological niche of long-term land use changes: The role of biophysical factors. Ecol. Indic. 2016, 60, 231-236. [CrossRef]

36. Fabbio, G.; Merlo, M.; Tosi, V. Silvicultural management in maintaining biodiversity and resistance of forests in Europe-the Mediterranean region. J. Environ. Manag. 2003, 67, 67-76. [CrossRef]

37. Fares, S.; Mugnozza, G.S.; Corona, P.; Palahi, M. Five steps for managing Europe's forests. Nature 2015, 519, 7-9. [CrossRef] [PubMed]

38. Dobbertin, M. Tree growth as indicator of tree vitality and of tree reaction to environmental stress: A review. Eur. J. For. Res. 2005, 124, 319-333. [CrossRef]

39. Lindner, M.; Maroschek, M.; Netherer, S.; Kremer, A.; Barbati, A.; Garcia-Gonzalo, J.; Seidl, R.; Delzon, S.; Corona, P.; Kolström, M.; et al. Climate change impacts, adaptive capacity, and vulnerability of European forest ecosystems. For. Ecol. Manag. 2010, 259, 698-709. [CrossRef]

40. Colantoni, A.; Ferrara, C.; Perini, L.; Salvati, L. Assessing trends in climate aridity and vulnerability to soil degradation in Italy. Ecol. Indic. 2015, 48, 599-604. [CrossRef]

41. Torras, O.; Saura, S. Effects of silvicultural treatments on forest biodiversity indicators in the Mediterranean. For. Ecol. Manag. 2008, 255, 3322-3330. [CrossRef]

42. Levin, S.A. Ecosystems and the Biosphere as Complex Adaptive Systems. Ecosystems 1998, 1, 431-436. [CrossRef]

43. Ringold, P.L.; Alegria, J.; Czaplewski, R.L.; Mulder, B.S.; Tolle, T.; Burnett, K. Adaptive monitoring design for ecosystem management. Ecol. Appl. 1996, 6, 745-747. [CrossRef]

44. Kelly, C.; Ferrara, A.; Wilson, G.A.; Ripullone, F.; Nolè, A.; Harmer, N.; Salvati, L. Community resilience and land degradation in forest and shrubland socio-ecological systems: Evidence from Gorgoglione, Basilicata, Italy. Land Use Policy 2015, 46, 11-20. [CrossRef]

45. Karamesouti, M.; Detsis, V.; Kounalaki, A.; Vasiliou, P.; Salvati, L.; Kosmas, C. Land-use and land degradation processes affecting soil resources: Evidence from a traditional Mediterranean cropland (Greece). Catena 2015, 132, 45-55. [CrossRef]

46. Salvati, L.; Becagli, C.; Bertini, G.; Cantiani, P.; Ferrara, C.; Fabbio, G. Toward sustainable forest management indicators? A data mining approach to evaluate the impact of silvicultural practices on stand structure. Int. J. Sustain. Dev. World Ecol. 2016, 24, 372-382. [CrossRef]

47. Latham, P.; Zuuring, H.; Coble, D. A Method for Quantifying Vertical Forest Structure. For. Ecol. Manag. 1998, 104, 157-170. [CrossRef]

48. Neumann, M.; Starlinger, F. The significance of different indices for stand structure and diversity in forests. For. Ecol. Manag. 2001, 145, 91-106. [CrossRef]

49. Fardusi, M.J.; Castaldi, C.; Chianucci, F.; Corona, P.; Mason, F.; Minari, E.; Puletti, N. A spatio-temporal dataset of forest mensuration for the analysis of tree species structure and diversity in semi-natural mixed floodplain forests. Ann. For. Sci. 2018, 75, 11. [CrossRef]

50. Del Río, M.; Bravo-Oviedo, A.; Pretzsch, H.; Löf, M.; Ruiz-Peinado, R. A review of thinning effects on Scots pine stands: From growth and yield to new challenges under global change. For. Syst. 2017, 26, eR03S. [CrossRef]

51. Becagli, C.; Puletti, N.; Chiavetta, U.; Cantiani, P.; Salvati, L.; Fabbio, G. Early impact of alternative thinning approaches on structure diversity and complexity at stand level in two beech forests in Italy. Ann. Silvic. Res. 2013, 37, 55-63. [CrossRef]

52. Chiavetta, U.; Skudnik, M.; Becagli, C.; Bertini, G.; Ferretti, F.; Cantiani, P.; Di Salvatore, U.; Fabbio, G. Diversity of structure through silviculture. Ital. J. Agron. 2016, 11, 18-22. 
53. Tabacchi, G.; Di Cosmo, L.; Gasparini, P.; Morelli, S. Stima del Volume e della Fitomassa delle Principali Specie Forestali Italiane, Equazioni di Previsione, Tavole del Volume e Tavole della Fitomassa Arborea Epigea; Consiglio per la Ricerca e la Sperimentazione in Agricoltura, Unita di Ricerca per il Monitoraggio e la Pianificazione Forestale: Trento, Italy, 2011; ISBN 9788897081111.

54. Cantiani, P.; Marchi, M. A spatial dataset of forest mensuration collected in black pine plantations in central Italy. Ann. For. Sci. 2017, 74, 50. [CrossRef]

55. Chianucci, F.; Salvati, L.; Giannini, T.; Chiavetta, U.; Corona, P.; Cutini, A. Long-term response to thinning in a beech (Fagus sylvatica L.) coppice stand under conversion to high forest in central Italy. Silva Fenn. 2016, 50, 1549. [CrossRef]

56. Cutini, A.; Chianucci, F.; Giannini, T.; Manetti, M.C.; Salvati, L. Is anticipated seed cutting an effective option to accelerate transition to high forest in European beech (Fagus sylvatica L.) coppice stands? Ann. For. Sci. 2015, 72, 631-640. [CrossRef]

57. Zitti, M.; Ferrara, C.; Perini, L.; Carlucci, M.; Salvati, L. Long-Term Urban Growth and Land Use Efficiency in Southern Europe: Implications for Sustainable Land Management. Sustainability 2015, 7, 3359-3385. [CrossRef]

58. Salvati, L.; Ferrara, A.; Mancino, G.; Kelly, C.; Chianucci, F.; Corona, P. A Multidimensional Statistical Framework to Explore Seasonal Profile, Severity and Land-Use Preferences of Wildfires in a Mediterranean Country. Int. For. Rev. 2015, 17, 485-497. [CrossRef]

59. Salvati, L.; Carlucci, M. The economic and environmental performances of rural districts in Italy: Are competitiveness and sustainability compatible targets? Ecol. Econ. 2011, 70, 2446-2453. [CrossRef]

60. Salvati, L.; Zitti, M. The Environmental "Risky" Region: Identifying Land Degradation Processes Through Integration of Socio-Economic and Ecological Indicators in a Multivariate Regionalization Model. Environ. Manag. 2009, 44, 888-898. [CrossRef] [PubMed]

61. Pommerening, A.; Särkkä, A. What mark variograms tell about spatial plant interactions. Ecol. Model. 2013, 251, 64-72. [CrossRef]

62. Zenner, E.K.; Hibbs, D.E. A new method for modeling the heterogeneity of forest structure. For. Ecol. Manag. 2000, 129, 75-87. [CrossRef]

63. Staudhammer, C.L.; LeMay, V.M. Introduction and evaluation of possible indices of stand structural diversity. Can. J. For. Res. 2001, 31, 1105-1115. [CrossRef]

64. Pretzsch, H. Canopy space filling and tree crown morphology in mixed-species stands compared with monocultures. For. Ecol. Manag. 2014, 327, 251-264. [CrossRef]

65. Cabon, A.; Mouillot, F.; Lempereur, M.; Ourcival, J.-M.; Simioni, G.; Limousin, J.-M. Thinning increases tree growth by delaying drought-induced growth cessation in a Mediterranean evergreen oak coppice. For. Ecol. Manag. 2018, 409, 333-342. [CrossRef]

66. Jonard, M.; Misson, L.; Ponette, Q. Long-term thinning effects on the forest floor and the foliar nutrient status of Norway spruce stands in the Belgian Ardennes. Can. J. For. Res. 2006, 36, 2684-2695. [CrossRef]

67. Fichtner, A.; Sturm, K.; Rickert, C.; von Oheimb, G.; Härdtle, W. Crown size-growth relationships of European beech (Fagus sylvatica L.) are driven by the interplay of disturbance intensity and inter-specific competition. For. Ecol. Manag. 2013, 302, 178-184. [CrossRef]

68. Winter, S.; Möller, G.C. Microhabitats in lowland beech forests as monitoring tool for nature conservation. For. Ecol. Manag. 2008, 255, 1251-1261. [CrossRef]

69. Mathys, A.; Coops, N.C.; Waring, R.H. Soil water availability effects on the distribution of 20 tree species in western North America. For. Ecol. Manag. 2014, 313, 144-152. [CrossRef]

70. Salvati, L.; Zitti, M.; Ceccarelli, T. Integrating economic and environmental indicators in the assessment of desertification risk: A case study. Appl. Ecol. Environ. Res. 2008, 6, 129-138. [CrossRef]

71. Salvati, L.; Zitti, M. Land degradation in the Mediterranean basin: Linking bio-physical and economic factors into an ecological perspective. Biota 2005, 5, 67-77. 
72. Pommerening, A. Approaches to quantifying forest structures. Forestry 2002, 75, 305-324. [CrossRef]

73. Recanatesi, F.; Clemente, M.; Grigoriadis, S.; Ranalli, F.; Zitti, M.; Salvati, L. A fifty-years sustainability assessment of Italian Agro-forest Districts. Sustainability 2016, 8, 32. [CrossRef]

(c)

(C) 2018 by the authors. Licensee MDPI, Basel, Switzerland. This article is an open access article distributed under the terms and conditions of the Creative Commons Attribution (CC BY) license (http:/ / creativecommons.org/licenses/by/4.0/). 